\title{
Harpacticoida (Crustacea: Copepoda) of the South China Sea: faunistic and biogeographical analysis
}

\section{Elena S. Chertoprud ${ }^{1}$, Hendrik Gheerardyn ${ }^{2, *}$, Samuel Gómez $^{3}$}

${ }^{1}$ Department of Hydrobiology, Biology Faculty, Moscow State University, Moscow 119899, Russia.

${ }^{2}$ Ghent University, Biology Department, Marine Biology Section, Campus Sterre, Krijgslaan 281-S8, B-9000 Gent, Belgium. *Corresponding author: hendrik.gheerardyn@ ugent.be

${ }^{3}$ Unidad Académica Mazatlán, Insituto de Ciencias del Mar y Limnología, Universidad Nacional Autónoma de México, Joel Montes Camarena s/n, Mazatlán, 82040, Sinaloa, México.

Key words: marine biogeography, tropical Indo-Pacific region, Harpacticoida

This paper has not been submitted elsewhere in identical or similar form, nor will it be during the first three months after its submission to Hydrobiologia. 


\begin{abstract}
Based on original and on published databases, a compendium of the Harpacticoida of the South China Sea is presented, and the distributional range of species is discussed. Up to now, a total of 77 harpacticoid species belonging to 57 genera and 19 families have been recorded in this region. Twenty of these species, collected in Nha Trang Bay (Vietnam), have not hitherto been described. The most speciose families are the Miraciidae (20 species) and the Laophontidae (9 species). Thirteen families were represented by one to three species only and six families by four to seven species. A brief comparison is presented between the harpacticoid fauna of the South China Sea, the Philippine Islands, the inner Malayan Archipelago (Java, Flores, Banda and Celebes Seas), New Guinea, the Yellow Sea and the Andaman and Nicobar Islands. The overall similarity between the species lists of these areas was observed to be extremely low (average value of Simpson index is $0.15 \pm 0.08$ ). The lists of planktonic species from the different areas showed the highest similarity. The lowest similarity (highest endemism) was observed between the lists of interstitial species. It is likely that one of the factors determining the differences between the faunas is the poor knowledge about the composition and distribution of benthic harpacticoids in tropical latitudes.
\end{abstract}




\section{Introduction}

The South China Sea is one of the major fringing seas of the tropical Indo-Pacific region. Its boundaries are defined by the peninsula of Indochina in the west, by the Greater Sunda Isles in the south and by the Philippine archipelago in the east. As for several other tropical seas, data on the composition of the harpacticoid fauna are scarce.

Some papers have been published about free-living (Baldari \& Cottarelli, 1986; Cottarelli \& Altamura, 1986; Schizas \& Shirley, 1994) and symbiotic (from ascidians' cavities and crabs' gill chambers) harpacticoid species (Sewell, 1940; Cottarelli et al., 2006) from shallow waters in the Philippines. Harpacticoids from several major estuaries in China have been described (Shen \& Tai, 1963, 1964, 1965), but the analysis of the marine harpacticoid fauna is still very limited (Shen \& Tai, 1973; Zhang \& Li, 1976). Recently, two species of Diarthrodes have been described from the coast of Vietnam (Gómez et al., 2008). Several relatively old works, whose data have been combined in Lang (1948), deal with the estuarine fauna of Thailand. Most research has focused on the distribution of zooplankton species. The distribution of planktonic harpacticoids from the northern and eastern South China Sea (e.g. Chen et al., 1974; Chen, 1992; Huys \& Conroy-Dalton, 2000; Tseng et al., 2008) and from the Gulf of Thailand (Lang, 1948) has been considered.

Because of the scarcity and scattered nature of the data about harpacticoids in the South China Sea, further progress in studying the regional fauna is impossible without reviews and compilations of the current knowledge, and the present paper is the first step in this difficult direction. In this paper, a list of the known harpacticoid copepods of the South China Sea is presented based on our own material and on published data. Also, a comparative biogeographical analysis of the fauna of the South China Sea and from a number of neighboring regions in the tropical and temperate zone is provided. 


\section{Materials and methods}

Sampling sites and procedure

The Maritime Department of the Russian-Vietnamese Tropical Research and Technology Center has been carrying out several studies about the marine benthic invertebrates in Nha Trang Bay (Vietnam) during the last 19 years (1990-2008). During this period, an extensive database on the composition and structure of both benthic and coral reef communities has been created.

Soft sediment samples were taken in Nha Trang Bay in April-May 2004. Samples were taken at 8 stations with different salinities, depth and sediment type. Samples in the littoral zone were taken during low tide with a sediment core; samples in the sublittoral zone were taken by scuba diving. A map with the stations, sampled at Nha Trang Bay, and characteristics of the main abiotic factors (sediment granulometry and salinity) are provided by Chertoprud et al. (in press), which deals with the diversity of the South China Sea harpacticoid taxocenes.

\section{Literature sources}

Data about the harpacticoid fauna of the South China Sea are derived from the following sources: Baldari \& Cottarelli (1986), Cottarelli \& Altamura (1986), Cottarelli et al. (2006), Gómez et al. (2008), Huys \& Conroy-Dalton (2000), Lang (1948), Pesce (2007), Schizas \& Shirley (1994), Shen \& Tai (1963, 1964, 1965, 1973), Tseng et al. (2008), and Zhang \& Li (1976). For the species lists of the Philippine Islands, the internal Malayan Archipelago Seas (the Java, Flores, Banda and Celebes Seas), New Guinea, the Yellow Sea (including the Kyushu and Ryukyu Islands) and the Andaman and Nicobar Islands (Indian Ocean) (Fig. 1), the following sources were used: Chang \& Kim (1991), Chang \& Song (1995), Cottarelli et al. (1986a, b), Cottarelli \& Mura (1980), Cottarelli (1986), Fiers (1982, 
1984a, b, 1986a, b, c, d, 1987a, b, 1988, 1992, 1993), Gee \& Mu (2000), Gheerardyn et al. (2006), Ho \& Hong (1988), Huys \& Conroy-Dalton (2000), Huys et al. (2005), Kim \& Kim (1998), Lang (1948), Miura (1962), Mu \& Huys (2002), Pesce (2007), Por (1964), Rao \& Ganapati (1969a, b), Rao (1993), Seifried (1997), Sewell (1940), Shen \& Bai (1956), Itô (1973, 1977, 1982, 1983), Wells et al. (1975), Wells \& Rao (1987). The references, that are provided in reviews as Lang (1948), Wells \& Rao (1987) and Kim \& Kim (1998) and are of interest to the studied region, have not been repeated here. Species lists which were compiled in reviews have been checked for accuracy and quality by evaluating the original references.

The list includes both planktonic and benthic forms, but does not take into account the vertical zonation of the species because information is too limited to assess littoral, sublittoral and abyssal species assemblages.

Taxonomy and life forms

The taxonomic system of the species list follows the «European Register of Marine Species» (Costello et al., 2001). The taxonomic status of Miraciidae follows Willen (2002). Nomenclature within families and genera and recognition of synonymous species was done using Bodin (1997). Species that were not present in this list were assigned to genera following Lang (1948) and Pesce (2007).

Harpacticoid species were allocated to life forms by Chertoprud et al. (2006) and phytal, planktonic, epibenthic, facultative interstitial (represented by small non-specialized species) and genuine interstitial (with vermiform and lanceolate habitus) forms were recognized.

Statistical analysis 
To compare the regional faunas, we calculated the percentage of overlap between regions and the proportions of endemic versus cosmopolitan species. The similarity of faunas between regions was estimated using the Simpson index $(S)$ for qualitative data (Urbakh, 1975): $S(x, y)=a /[a+\min (b, c)]$; where $a$ is the number of common species of fauna groups $x$ and $y$; and $b$ and $c$ are the numbers of species restricted to one of the groups. This index is not sensitive to negative coincidences of properties, but it is convenient for estimating the similarity between faunas from different regions when the individual lists under comparison contain only limited parts of the total species set. This index is often used for biogeographical analyses of fossil (Ridley, 2004) and recent faunas (Murray et al., 2002; Azeria, 2004).

For the graphical representation of the similarity in species composition between the regions, we have applied cluster analysis using the mean addition technique integrated in the Systat 7.0 software package. As a measure of similarity, we have used the Euclidean distance between the faunas of the regions: $E(x, y)=[b+c]^{1 / 2}$; where $b$ and $c$ represent the number of species restricted to species group $x$ and $y$, respectively.

\section{Results}

Species richness and composition of the South China Sea harpacticoid copepod fauna.

Based on original and published data, a list of the known harpacticoids of the South China Sea was prepared (see Appendix). At present, 77 species, 57 genera and 19 families of Harpacticoida have been reported from the South China Sea. Twenty species, found in the Nha-Trang Bay (Vietnam), have not hitherto been described. Fourteen species from NhaTrang Bay were identified to the genus level because only one sex was found. Sexual dimorphism in harpacticoid species mostly occurs in the characteristics of body and legs. Exact species identification based on one sex is restricted in certain occasions, when the key 
characteristic is present in the other sex (e.g. in two species of Amphiascus from Nha-Trang Bay, represented by females only). The most species-rich families are Laophontidae and Miraciidae, with 9 and 20 species, respectively. The species:genus ratio is extremely low (1.35).

Epibenthic harpacticoids (inhabiting silt deposit and the surface of soft sediments) dominate and constitute $61 \%$ of the species of the South China Sea. Macrophyte-associated fauna in the South China Sea represent only $4 \%$ of the total number of species and belong to the families Peltidiidae (Eupelte acutispinis), Thalestridae (Eudactylopus sp.) and Tisbidae (Zosime sp.). This is probably due to a low exploration of this habitat, and to the substitution of macrophytes by the coral belt in tropical areas (Vinogradova, 1977). Genuine interstitial vermiform and lanceolate Harpacticoida (which inhabit the space between sediment particles) are represented by the families Darcythompsoniidae (Leptocaris sp.), Ectinosomatidae (Hastigerella sp.), Laophontidae (Elapholaophonte decaceros) and Paramesochridae (Apodopsyllus biarticulatus, Scottopsyllus sp., Paramesochra sp.), and make up $7.8 \%$ of the total number of species. Even in areas with a relatively well studied fauna, small genuine interstitial forms are usually underestimated due to limitations of the sampling techniques (Chertoprud \& Garlitskaya, 2007). Most likely, further research will discover more species and will increase the number of interstitial species in the South China Sea. The number of facultative interstitial forms, represented by small non-specialized Harpacticoida, is much higher: Ameiridae (Ameira sp., Nitokra platypus bakeri, N. arctolongus, N. cf. affinis, N. sp.), Canthocamptidae (Mesochra quadrispinosa, M. prowaseki, M. cf. pygmaea), Miraciidae (Amphiascus sp. 1, sp. 2, sp. 3, Amphiascoides sp., Bulbamphiascus sp.) and the species of this group make up $16.9 \%$ of the total fauna. Two species, Carcinocaris serrichelata and Xanthilaophonte trispinosa, live in the gill chambers of the Yellow Crab (Cottarelli et al., 2006). The planktonic Harpacticoida are represented by Euterpina acutifrons, Clytemnestra 
hendorffi quinquesetosa, Clytemnestra scutellata, Microsetella rosea, Microsetella norvegica and Macrosetella gracilis. They constitute $7.8 \%$ of the total species and have been studied most comprehensively.

In general, all species can be divided into three groups: endemics, tropical species and cosmopolitans. The richest group is provided by the endemic harpacticoids that only occur in the South China Sea (44 species). The distribution range of 18 species goes beyond the South China Sea boundaries. Of these, the distribution of ten species is restricted to subtropical and tropical latitudes, and eight species (five of which are planktonic) are cosmopolitans. The distribution range of the 18 species, which we found to be wider distributed than in the South China Sea, is briefly discussed as follows:

1) Tropical Group.

A) Indo-Pacific section. Nitokra platypus bakeri was found both near the southern coast of China, and near the coasts of Japan and The Philippines. Stenhelia latioperculata has been recorded in the Sea of Japan. Sinotachidius vicinospinalis occurs along the southern coasts of China and Korea and Mesochra prowaseki and Clytemnestra hendorffi quinquesetosa occur in the South China Sea and the Seas of the Malayan Archipelago. Brianola elegans and Schizopera longirostris have been reported from the South China Sea and also from waters near New Guinea and Australia. Xanthilaophonte trispinosa has been found around the Philippine Archipelago, as well as in the eastern part of the Indian Ocean.

B) Widely-tropical section. Paramphiascella langi is known from the coasts of China and Algeria. Quinquelaophonte quinquespinosa shows a wide distribution range, along the coasts of India, Australia, Indonesia and Africa, which is extended to the Mediterranean Sea.

2) Cosmopolitans.

Longipedia scotti has been collected from New Guinea, the Andaman Islands and the South China Sea, and also near all coasts of Europe. Schizopera clandestina has been found 
near the coasts of the Malayan Archipelago and New Zealand, in the Atlantic and Mediterranean waters of Europe and near the coast of northern Africa. The distribution range of Onychocamptus mohammed includes the South China Sea, all coasts of Europe, northern and central Africa, the Caribbean Sea and waters of Brazil. Euterpina acutifrons, Clytemnestra scutellata, Microsetella rosea and Macrosetella gracilis have been found among the plankton near the coasts of Australia, the Malayan Archipelago, India, Europe and North and South America. Microsetella norvegica shows a similar distribution range, but does not occur in the southern hemisphere.

Comparative biogeographical analysis of the faunas

A comparison of the harpacticoid copepod composition of the South China Sea, the Philippine Islands, the internal Malayan Archipelago Seas (i.e. the Java Sea and the Flores, Banda and Celebes Seas), New Guinea, the Yellow Sea and the Andaman and Nicobar Islands was performed. There are strong differences in sampling effort between seas and between regions. The fauna of the Andaman and Nicobar Islands is relatively well known, with 40-50 published papers in this region. Data on the fauna of the Yellow Sea and the coasts of New Guinea are relatively scarce (around 20-30 papers available for each region). The number of contributions to the fauna of the South China Sea (19) is comparable to those on the two regions above. Short lists of species are available for the Philippine archipelago, the Java Sea, and the Flores, Banda and Celebes Seas. Knowledge about Harpacticoida of the two latter regions is based on the results from several expeditions which will be thoroughly revised in the near future.

About 400 species of Harpacticoida are known from the studied region (which covers more than half of the tropical Indo-Pacific) (Table 1). Of these, nearly 221 species are endemic. Another 124 species are considered conventional endemics. This means that they 
have been reported from one of the six areas considered in this study, and also in one or few localities outside the Indo-Pacific region considered here (Chertoprud \& Garlitskaya, 2007). These two groups make up $86 \%$ of the total number of species in the region. Only 46 species were found in 2-4 areas of the overall Indo-Pacific sector. Among them, 29 species are cosmopolitans with their distribution range extending to the Mediterranean Sea, the central and northern Atlantic, and even the Arctic region. Seventeen species are confined to the tropics. The number of endemic species in the different regions is shown in Figure 1.

The average similarity between the species lists of the regions is very low (average Simpson index is $0.15 \pm 0.08$ ). The harpacticoid species list from the Yellow Sea (which extends to temperate latitudes) differs strikingly from that of other tropical regions (average Simpson index is $0.09 \pm 0.02$ ). The faunas of the best studied tropical regions (New Guinea and the Andaman and Nicobar Islands) are most similar to each other (Simpson index is 0.28), and to the poorly studied fauna of the internal Malayan Archipelago Seas (Fig. 1). Also, the cluster analysis indicates that the faunas are very different and do not cluster into distinct groups (Fig. 2). The species-rich fauna of the Andaman and Nicobar Islands is most clearly separated.

It is interesting to note that the index of similarity between the relatively well studied fauna from the Caribbean Sea and Bahamas Islands (178 species (Suárez-Morales et al., 2006)) and the two best studied regions (New Guinea and the Andaman and Nicobar Islands) in the Indo-Pacific is $0.24 \pm 0.01$. Fourty species are common to these three regions. Of these, 23 species have a wide boreal distribution or are cosmopolitan. Seventeen species have not been recorded north of $40^{\circ} \mathrm{N}$ and probably have a circum-tropical distribution.

The number of species within the life form groups varies considerably between the regions of the Indo-Pacific (Table 2). This is due to natural variation in the spread of taxa, and to the used techniques and priorities of researchers. For example, studies on 
Harpacticoida of the South China Sea focused primarily on commensal species associated with a variety of invertebrates (e.g. Cottarelli et al., 2006). For the Yellow Sea, Kim \& Kim (2005) described species of the families Porcellidiidae and Pseudotachidiidae, while the other taxa received little attention.

The number of known species of genuine interstitial form in a given region can be considered as a measure of the intensity of investigation of the harpacticoid fauna. Most likely, the best studied region in this respect appears to be the Andaman and Nicobar Islands, where 16 species of this life form were found. In the Yellow Sea and internal Malayan Archipelago Seas, genuine interstitial species were not found at all. In this group of life forms, $54 \%$ of the total number of species is endemic to different regions.

Most of the facultative interstitial species were found in the South China Sea, and in the Andaman and Nicobar Islands (12 and 13 species, respectively). The proportion of the facultative interstitial fauna varies greatly in different regions, reaching its maximum in the South China Sea (16.9\%) and its minimum in the Philippine Islands (6.7\%). The proportion of endemics in this life form is higher $(75.7 \%)$ in comparison with species of genuine interstitial form. On the other hand, the similarity between the regions for this life form is very low (average Simpson index is $0.04 \pm 0.09$ ).

The number of phytal Harpacticoida varies greatly from region to region. Phytal species have not been recorded yet from the Philippine Islands. In the Yellow Sea, they make up a third (32.9\%) of all species. Bohai bay (the northernmost region of the Yellow Sea) lies in the temperate zone, where coral reefs are replaced by macrophyte assemblages. Therefore, it is here that the diversity of alga-associated fauna gets its maximum. In this region both Chinese and Korean taxonomists have described more than a dozen of endemic species of Porcellidiidae, Peltidiidae and Thalestridae. Therefore, it is not surprising that of all phytal 
species, the proportion of endemics is high (55\%). The similarity of phytal harpacticoids between the regions for this life form is not high (average Simpson index is $0.09 \pm 0.13$ ).

Epibenthic forms in all considered regions provide 50 to $80 \%$ of the total number of species, and $61 \%$ of the species are endemic. The similarity between regions for this life form is low (average Simpson index is $0.07 \pm 0.07$ ). In the Philippines, more than one third of epibenthic species belong to the family Aegisthidae, which occur typically in the lower sublittoral and abyssal.

The composition of planktonic harpacticoid fauna in the different regions is nearly the same. In most areas, four cosmopolitan species occur: Macrosetella gracilis, Microsetella rosea, Clytemnestra scutellata and Euterpina acutifrons. The similarity between the regions of the planktonic fauna is high (average Simpson index is $0.91 \pm 0.14$ ).

\section{Discussion}

More than $50 \%$ of the species of the South China Sea have not been found in other parts of the world and could therefore be considered as endemics. However, studies of tropical harpacticoid copepods and their habitats are at the very beginning. Therefore, it is possible that our conception of species distributions will change in the future.

The overlap of the South China Sea fauna with the faunas of the neighboring regions is not high: four species (5.2\% of the fauna) are common with the Yellow Sea, three (3.9\%) with the Philippines, seven (9.1\%) with the assemblage of the Malayan Archipelago Seas and eight species with New Guinea (10.4\%) and with the Andaman and Nicobar Islands (10.4\%). Hicks (1977) compared the species composition of the New Zealand Harpacticoida with the faunas of continental coasts and obtained similar percentages. Cook Strait had five harpacticoid species in common with south-eastern Australia (7\% of the total fauna), four 
(6\%) with the coast of southwest Africa, and 14 species (17\%) with the southern tip of the South American coast.

Overall, the similarity between the faunas of all considered regions is extremely low (average Simpson index is $0.15 \pm 0.08$ ). The species lists of single seas contain a high proportion of endemics, as well as representatives that were not encountered in any other of the six compared regions, but were observed in one or a few localities of the World's Ocean, outside the Indo-Pacific region considered here (i.e. conventional endemics). Within the regions, the total proportion of endemic and conventional endemic species ranged from $53.7 \%$ (the Java Sea and the Flores, Banda and Celebes seas) to $84.4 \%$ (Andaman and Nicobar Islands) (Table 1). Concerning the biogeographical variability of the harpacticoid fauna, Lang (1948) and Hicks \& Coull (1983) stated that the species composition of these highly mobile copepods changes little from region to region. In the Indo-Pacific sector, we are apparently faced with a contradiction to this thesis: the similarity between the South China Sea and the adjacent regions is low.

It is necessary to note that the real similarity of faunas of the studied regions can differ from the already marked one (average Simpson index is $0.15 \pm 0.08$ ), in connection with the presence of cryptic species, but also because of the underestimation of intraspecific variability. Probably, some species with wide distribution areas will turn out to be a series of twin species. For example, karyological analysis and intercrossing of populations of the "cosmopolitan" harpacticoid Tigriopus californicus have resulted in the description of two twin species (Soyer et al., 1987). On the other hand, the description of narrow-endemic species could turn out to be a consequence of the underestimation of intraspecific variability which practically has not been studied for meiobenthic organisms. For example, three harpacticoid species studied in this respect - Tigriopus californicus, Cletocamptus deitersi and Microarthridion littorale - have shown an unexpectedly high level of genetic diversity, both 
in areas spanning hundreds of kilometers, and within the limits of a separate bay - not spanning more than ten kilometers (Burton, 1990; Burton \& Lee, 1994; Schizas et al., 1999, 2002). For the moment, it is difficult to estimate the real contribution of the above described tendencies to the species diversity of the region under study. Presently, methods of genosystematics have been applied only to a small number of taxons of meiobenthic organisms as a whole and harpacticoid copepods in particular.

Inevitably, the question arises what causes this low similarity between the harpacticoid assemblages within and outside the South China Sea?

The studied seas are situated in the subtropical and tropical climatic zone, except for the Yellow Sea which enters the boreal zone. The waters of these seas are patchily interlinked by wide straits (e.g. Malacca, Taiwan, Karimata, Makassar, Ceram and Balabac Straits), and by the network of monsoon and trade-wind drifts. The possibility of the exchange of water masses is supported by the fact that the planktonic harpacticoid fauna is virtually the same in the entire Indo-Malayan region. However, for the distribution of planktonic calanoids, it has been shown that there is a thermal and hydrological barrier in the western region of the IndoPacific, which is responsible for differences in fauna composition on both sides of the barrier (especially for the stenotherm Pontellidae) (Fleminger, 1986). In the case of planktonic harpacticoids, the similarity between faunas on both sides of this barrier is remarkable and agrees with the high tolerance of these mainly cosmopolitan species. Certain benthic harpacticoids are capable of migrating for hundreds of kilometers by moving with the bottom water or on fragments of macrophytes (Hauspie \& Polk, 1973). Certain species (e. g. Scutellidium longicauda, Dactylopodia tisboides and Paralaophonte congenera) have been reported to show transoceanic migrations on the fragments of macrophytes (Hicks, 1977). The capability for migration is apparent for most harpacticoid life forms, while species with a genuine interstitial form show a lower degree of mobility (Chertoprud et al., 2006). Evidently, 
future studies are necessary to define the exact distribution ranges of many species, which at present are known only from a small area, but are potentially able to have a wide distribution. Thus, it is clear that the reason for the strong differences between the areas is not the isolation from each other. The similarity between the faunas of New Guinea, the Andaman and Nicobar Islands and the Caribbean Sea and Bahamas Islands, which are thousands and even tens of thousands kilometers apart, once again supports this statement. It should be noted that the distribution of planktonic calanoids is more dependent on the climatic and hydrological structure of regions than in mainly benthic groups (for example, harpacticoids) (Voronov at al., 2002). The distribution of benthic harpacticoids is conservative throughout the year and is more related to the geological history of the region. The significance of a biogeographical boundary for pelagic copepods is questionable for benthic copepods.

The assumption that the similarity is low due to biogeographical boundaries in the considered sector of the Indo-Pacific Ocean is questionable as well. According to the shelf zonation for macrobenthic invertebrates (Brachiopoda) (Zezina, 1976) and marine amphipods (Guryanova, 1964), all considered areas belong to the Indo-Malayan subregion of the IndoWest Pacific region. The only exception is the northern area of the Yellow Sea, which is sometimes referred to as the Japanese subregion of the Indo-West Pacific region (Zezina, 1976). Wallace, Sklater, Weber and Lydekker lines, which cross the straits of the Malayan Archipelago, and divide the Asian and Australian fauna are significant only for terrestrial vertebrates, and in a less degree for insects and plants. For marine and brackish water organisms, these biogeographical boundaries are of no importance (Keast, 1988).

We here analyse the possible influence of historical/geological factors on the biodiversity of Harpacticoida in the considered region. According to Hall (2002), the complex of seas of the East Indo-Pacific lays on the joint of several large lithospheric plates (Eurasian, Indian-Australian, Philippine). It is supposed that in the Neogene collisions of fragments of 
lithosperic plates have resulted in the creation of numerous shallow water areas in the Malayan archipelago, which has given an impulse to further exuberant formation of species (first of all, of the coral fauna) (Pandolfi, 1993; Wilson \& Rosen, 1998). Presumably, in the area named "East Indies Triangle", which extends from north of the Philippines, south-west across the Malayan Peninsula, and eastward beyond New Guinea, there is a powerful centre of origin and evolutionary radiation (Briggs, 2004). Intuitively, we agree that this area can be a centre of high species diversity for harpacticoid copepods as well. However, our data on this group yet do not confirm the statement by Briggs (2004). For example, the fauna of the Andaman and Nicobar Islands (184 species) is much more diverse than the fauna of the water areas of the East Indies Triangle (128 species). Further study of the fauna will probably result in a change of this situation.

In the works by Santini \& Winterbottom (2002) and Halas \& Winterbottom (2009), the theory of vicariant biogeography has been applied to study the evolution of the coral reef fauna (including Invertebrata) in the Indo-western Pacific region and to estimate the influence of historical/geological processes on species formation. During the analysis of cladograms, formed according to the distribution of taxons, numerous areas have been distinguished of which the boundaries however have been drawn in an arbitrary way to some extent. This is related to the fact that taxonomic groups included into the analysis (reef-building corals, nudibranchs and specialized coral fishes) are strictly associated with the coastal shallow zone. At the same time, the borders of areas pass through deep oceanic zones where these neritic species simply do not occur. Thus, the data of zonation are not applicable for the quickly multiplying, freely current-transported Harpacticoida which also frequently occupy a wide spectrum of biotopes, as well as for many other groups of sea organisms. The narrow spectrum of objects in the analysis does not give an opportunity to draw exact conclusions about the zonation of the region. 
It is likely that an important factor responsible for the remarkable differences between the faunas is the poor exploration of the composition and distribution of Harpacticoida in tropical latitudes. Low species: genus ratios of the faunas of these areas (Table 1) underscore this fact. In the well-studied North Sea and Mediterranean Sea (each being 10 times smaller than the total surface area of the Malayan Archipelago Seas) about 700 and 500 species have been reported, respectively (Pesce, 2007; Garlitskaya et al., 2009). Moreover, the number of taxonomical and faunistical publications about these seas is approximately 1000 (Garlitskaya et al., 2009), while the number of works on the Indo-Pacific sector is not more than about 200. Particular information on the harpacticoid composition of the Java Sea, the Flores, Banda and Celebes seas, and a number of adjacent small seas of the Malayan Archipelago is still based on data collected by the Siboga expedition in 1899-1900 (A. Scott, 1909). It should be noted that an increase of harpacticoid species richness in the meridional direction from the Arctic to the temperate and subtropical latitudes has been suggested (Hicks \& Coull, 1983; Wells, 1986), with the fauna of the tropics as the most diverse (Lang, 1948; Abele, 1982).

Against the background of a low level of exploration of the East Indo-Pacific, it is hard to identify the impact of other factors determining a high diversity of the group in the region. Most likely, dynamics of oceanographic conditions caused by geological processes, and biogeographical fragmentation of the region have influenced the faunas of Harpacticoida. However, it is hard to give an exact estimation of the contribution of these factors to the formation of the diversity of the group as, in connection with a low level of exploration of the region, their impact becomes difficult to observe.

Obviously, the question arises whether comparison of not fully studied regional faunas is allowed? At present, the species list of meiobenthic organisms for any quite extensive region is not complete and does not reflect its real faunal diversity (Lambshead, 1993). However, if we draw from this fact the conclusion that comparison of species lists is 
impossible until the last taxon is described, there is a risk to postpone the analysis of all macroecological, including biogeographical problems up to "future centuries". In particular, the process of subdivision of already well-established taxons, which has begun in connection with the perfection of the techniques of molecular taxonomy, is still far from complete. In our opinion, such position is not acceptable. The absence of any comparative analysis of the biodiversity of known faunas not only will narrow the spectrum of perceptions about the specificity of organization of meiobenthic communities in separate regions, but also will result in the destruction of a general system approach in the description of structure of interrelations in the world fauna as a whole.

To date, the fauna of tropical latitudes has generally been poorly studied. In the IndoPacific region, the harpacticoids of phytal and interstitial zones have received most attention until now, as well as those living commensally in specific habitats (such as living coral reefs and crabs' gill chambers). According to Wells (1986), the number of harpacticoid species of tropical waters did not exceed 800 in 1986. Our literature data show that in the last 20 years not more than 400 species were added. Therefore, it is not possible yet to assess a detailed biogeographical zonation for harpacticoids in the tropics, with the allocation of specific faunas to individual provinces. To assess the biogeographical zonation of harpacticoids in the Indo-Pacific, we find it essential that for each of the compared regions two thirds of the species should be known or the faunas of the compared regions should consist of at least 200 species. At present, we estimate that not more than one fifth of the harpacticoid species in the Indo-Pacific region is known, and the local, known faunas of the compared regions have only from 41 (Malayan Archipelago Seas) to 184 (Andaman and Nicobar Islands) species. Further biogeographical analyses should be based on the description of the harpacticoid fauna, the exploration of understudied habitats (such as the sublittoral zone) and the provision of species checklists for these regions. 


\section{Acknowledgments}

This work was supported by the Russian Foundation for Basic Research (proposal № 04-05-64734). The authors thank their colleagues Dr. T.A. Britaev and Dr. A.A. Udalov from the Maritime Department of the Russian-Vietnamese Tropical Research and Technology Center for providing the materials for this work.

\section{References}

Abele, L. G., 1982. Biogeography. In Bliss, D. E. (ed), The Biology of Crustacea. Vol. 1. Systematics, the Fossil Record, and Biogeography. Academic Press, New York: 242304.

Azeria, E. T., 2004. Terrestrial bird community patterns on the coralline islands of the Dahlak Archipelago, Red Sea, Eritrea. Global Ecology and Biogeography 13: 177-187.

Baldari, F. \& V. Cottarelli, 1986. A new species of the genus Paralaophontodes (Crustacea: Copepoda: Harpacticoida) from interstitial waters of Mindoro Island (The Philippines). Publications of the Seto Marine Biological Laboratory 31: 163-168.

Bodin, P., 1997. Catalogue of the new marine Harpacticoid Copepods (1997 Edition). Documents de Travail de l'Institut Royal des Sciences Naturelles de Belgique 89: 1304.

Briggs, J. C., 2004. A marine center of origin: reality and conservation. In Lomolino, M. V. \& L. R. Heaney (eds), Frontiers of biogeography. Sinauer Associates, Sunderland, Massachusetts: 255-269.

Burton, R. S., 1990. Hybrid breakdown in developmental time in the copepod Tigriopus californicus. Evolution 44: 1814-1822. 
Burton, R. S. \& B. N. Lee, 1994. Nuclear and mitochondrial gene genealogies and allozyme polymorphism across a major phylogeographic break in the copepod Tigriopus californicus. Proceedings of the National Academy of Sciences of the United States of America 91: 5197-5201.

Chang, C. Y. \& H. S. Kim, 1991. Harpacticella itoi, a new harpacticoid species from Korea (Copepoda: Harpacticoida: Harpacticidae). Korean Journal of Systematic Zoology 7: 73-80.

Chang, C. Y. \& S. J. Song, 1995. Marine harpacticoid copepods of genus Eudactylopus (Harpacticoid, Thalestridae) in Korea. Korean Journal of Systematic Zoology 11: 379 388.

Chen, Q. C., 1992. Zooplankton of China Seas. Vol. 1. Science Press, Beijing, China.

Chen, Q. C., S. Z. Zhang \& S. Z. Zhu, 1974. On planktonic copepods of the Yellow Sea and the East China sea II. Cyclopoida and Harpacticoida. Studia Marina Sinica 9: 27-76.

Chertoprud, E. S. \& L. A. Garlitskaya, 2007. A comparative analysis of the Harpacticoida (Copepoda) faunas from the northern and southern seas of Russia. Oceanology 47: 110.

Chertoprud, E. S., S. Gómez \& H. Gheerardyn, in press. Harpacticoida (Copepoda) Fauna and Taxocen Diversity of the South China Sea. Oceanology.

Chertoprud, E. S., M. V. Chertoprud, D. V. Kondar', P. N. Kornev \& A. A. Udalov, 2006. Harpacticoida taxocen diversity in the silt-sand intertidal zone of Kandalaksha Bay of the White Sea. Oceanology 46: 10-19.

Costello, M. J., C. Emblow \& R. White, 2001. European register of marine species. A checklist of the marine species in Europe and a bibliography of guides to their identification. Collection Patrimoines Naturels, Vol. 50. Publications Scientifiques du Muséum National d'Histoire Naturelle, Paris, France. 
Cottarelli, V., 1986. Laophontidae di acque interstiziali litorali dell'Indonesia. Bollettino del Museo Civico di Storia Naturale di Verona 12: 283-297.

Cottarelli, V. \& S. Altamura, 1986. Una nuova specie di Apodopsyllus (Crustacea, Copepoda, Harpacticoida) di acque interstiziali litorali delle Filippine: Apodopsyllus biarticulatus n. sp. Bollettino del Museo Civico di Storia Naturale di Verona 12: 299-305.

Cottarelli, V. \& G. Mura, 1982. Remarks on the genus Afrolaophonte (Crustacea, Copepoda, Harpacticoida) and description of three new species. Vie et Milieu 31: 153-161.

Cottarelli, V., M. C. Bruno \& R. Berera, 2006. Variazioni sul tema I: description of Carcinocaris serrihelata, gen. nov. sp. nov., associated with xanthid crabs and new data on the distribution of Xanthilaophonte trispinosa (Copepoda: Harpacticoida). Vie et Millieu 56: 1-11.

Cottarelli, V., A. C. Puccetti \& P. E. Saporito, 1986a. Osservazioni sul genere Psammopsyllus (Copepoda, Harpacticoida, Cylindropsyllidae) e descrizione di tre nuove specie. Bollettino del Museo Civico di Storia Naturale di Verona 11: 1-29.

Cottarelli, V., A. C. Puccetti \& P. E. Saporito, 1986b. Indolaophonte ramai n. gen. n. sp. (Crustacea, Copepoda, Harpacticoida) di acque interstiziali litorali dell'isola di Bali (Indonesia). Bollettino del Museo Civico di Storia Naturale di Verona 12: 273-281.

Fiers, F., 1982. New Canuellidae from the northern coast of Papua New Guinea (Copepoda: Harpacticoida). Bulletin de l'Institut Royal des Sciences Naturelles de Belgique 54: 132.

Fiers, F., 1984a. A new record of Ellucana longicauda Sewell, with the description of the male (Copepoda: Harpacticoida: Canuellidae). Indo-Malayan Zoology 2: 177-185.

Fiers, F., 1984b. Harpacticoid copepods from the West Indian Islands: Canuellidae and Longipediidae (Copepoda, Harpacticoida). Bijdragen tot de Dierkunde 54: 197-210. 
Fiers, F., 1986a. Feregastes wellensi n. gen., n. sp., a new genus of the family Tegastidae (Copepoda, Harpacticoida) from the Andaman Islands. Crustaceana 51: 277-285.

Fiers, F., 1986b. Harpacticoid copepods from the West Indian Islands: Laophontidae (Copepoda, Harpacticoida). Bijdragen tot de Dierkunde 56: 132-164.

Fiers, F., 1986c. Harpacticoid copepods from the West Indian Islands: Darcythompsoniidae (Copepoda, Harpacticoida). Bijdragen tot de Dierkunde 56: 282-290.

Fiers, F., 1986d. New and interesting copepods (Crustacea, Copepoda) from brackish waters of Laing Island (Northern Papua, New Guinea). Bulletin de l'Institut Royal des Sciences Naturelles de Belgique 56: 99-120.

Fiers, F., 1987a. Enhydrosoma vervoorti spec. nov., a new harpacticoid copepod from India (Harpacticoida: Cletodidae). Zoologische Mededelingen 61: 295-302.

Fiers, F., 1987b. Intercletodes interita n.gen., n.sp. and Orthopsyllus coralliophilus n.sp., two new copepods from the northern coast of Papua New Guinea (Copepoda, Harpacticoida). Bulletin de l'Institut Royal des Sciences Naturelles de Belgique 57: $123-132$.

Fiers, F., 1988. Probosciphontodes n. gen., a new genus of the family Ancorabolidae, with the description of two new species (Copepoda, Harpacticoida). Bulletin de l'Institut Royal des Sciences Naturelles de Belgique 58: 75-83.

Fiers, F., 1992. Metis reducta n. sp. and Laubieria tercera n. sp. (Harpacticoida, Metidae) from the southern coast of Papua, New-Guinea. Belgian Journal of Zoology 122: 3751.

Fiers, F., 1993. The laophontid genus Loureirophonte Jakobi, 1953 (Copepoda, Harpacticoida). Zoologische Mededelingen 67: 207-238.

Fleminger, A. 1986. The Pleistocene equatorial barrier between the Indian and Pacific oceans and a likely cause for Wallace's Line. Pelagic biogeography. UNESCO technical papers in marine science 49: 84-97. 
Garlitskaya, L. A., E. S. Chertoprud, D. V. Kondar' \& A. I. Azovsky, 2009. Large-scale patterns in harpacticoid copepod diversity and distribution. Abstract book of the World Conference on Marine Biodiversity: 99-100.

Gee, J. M. \& F. H. Mu, 2000. A new genus of Cletodidae (Copepoda; Harpacticoida) from the Bohai Sea, China. Journal of Natural History 34: 809-822.

Gheerardyn, H., F. Fiers, M. Vincx \& M. De Troch, 2006. Peltidiphonte gen. n., a new taxon of Laophontidae (Copepoda, Harpacticoida) from coral substrates of the Indo-West Pacific Ocean. Hydrobiologia 553: 171-199.

Gómez, S., E. S. Chertoprud \& F. N. Morale-Serna, 2008. New species of the genus Diarthrodes Thomson, 1882 (Copepoda: Harpacticoida: Thalestridae) from Vietnam and North-western Mexico. Cahiers de Biologie Marine 49: 123-150.

Gur'ianova, E. F., 1964. Zoogeographical zoning of the benthic fauna of the World Ocean (benthic fauna of the continental shelf). In Monin, A. S. (ed), Physiographic atlas of the world. AS USSR, Moskow. Map 68B.

Halas, D. \& R. Winterbottom, 2009. A phylogenetic test of multiple proposals for the origins of the East Indies coral reef biota. Journal of Biogeography 36: 1847-1860.

Hall, R., 2002. Cenozoic geological and plate tectonic evolution of SE Asia and the SW Pacific: computer-based reconstructions, model and animations. Journal of Asian Earth Sciences 20: 353-431.

Hauspie, R. \& P. H. Polk, 1973. Swimming behaviour patterns in certain benthic harpacticoids (Copepoda). Crustaceana 25: 95-103.

Hicks, G. R. F., 1977. Species composition and zoogeography of marine phytal harpacticoid copepods from Cook Strait, and their contribution to total phytal meiofauna. New Zealand Journal of Marine and Freshwater Research 11: 441-469.

Hicks, G. R. F. \& B. C. Coull, 1983. The ecology of marine meiobenthic harpacticoid copepods. Oceanography and Marine Biology. An Annual Review 21: 67-175. 
Huys, R. \& S. Conroy-Dalton, 2000. Generic concepts in the Clytemnestridae (Copepoda: Harpacticoida): revision and revival. Bulletin of the Natural History Museum London, Zoology Series 66: 1-48.

Huys, R., S. Ohtsuka, S. Conroy-Dalton \& Y. Kikuchi, 2005. Description of two new species of Neotachidius Shen \& Tai, 1963 (Copepoda, Harpacticoida, Tachidiidae) from Korean brackish waters and proposal of a new genus for Tachidius (Tachidius) vicinospinalis Shen \& Tai, 1964. Zoological Journal of the Linnean Society 143: 133159.

Ho, J. \& J. Hong, 1988. Harpacticoid copepods (Thalestridae) infesting the cultivated Wakame (brown alga, Undaria pinnatifida ) in Korea. Journal of Natural History 22: 1623-1637.

Itô, T., 1973. Three species of marine harpacticoid copepods from Amakusa, Kyushu. Journal of the Faculty of Science Hokkaido University 18: 516-531.

Itô, T., 1977. New species of marine harpacticoid copepods of the genera Harpacticella and Tigriopus from the Bonin Islands, with reference to the morphology of copepodid stages. Journal of the Faculty of Science Hokkaido University 21: 61-91.

Itô, T., 1982. Harpacticoid copepods from the Pacific abyssal off Mindanao. I. Cerviniidae. Journal of the Faculty of Science Hokkaido University 23: 63-127.

Itô, T., 1983. Harpacticoid copepods from the Pacific abyssal of Mindanao. II. Cerviniidae (cont.), Thalestridae, and Ameiridae. Publications of the Seto Marine Biological Laboratory 28: 151-254.

Keast, J. K., 1988. In the steps of Alfred Russel Wallace: biogeography of Asian-Australian interchange zone. Evolution, time and space. The emergence of the biosphere 23: 319351. 
Kim, S. H. \& V. Kim, 1998. Alteuthoides affinis, a new peltidiid copepod (Harpacticoida) associated with the sponge from Cheju Island, Korea. Korean Journal of Biological Sciences 2: 203-208.

Kim, S. H. \& V. Kim, 2005. Endemic species of Korea. Harpacticoida. Seul, Korea. Vol. 2, $44-47$.

Lambshead, P. J. D., 1993. Recent developments in marine benthic biodiversity research. Oceanis: Série de Documents Océanographiques 19: 5-24.

Lang, K., 1948. Monographie der Harpacticiden, I \& II. Nordiska Bokhandeln, Stockholm.

Miura, Y., 1962. Subterranean harpacticoid copepods of the Amami Group of the Ryukyu Islands. Annotationes Zoologicae Japonenses 35: 95-105.

Mu, F. H. \& R. Huys, 2002. New species of Stenhelia (Copepoda, Harpacticoida, Diosaccidae) from the Bohai Sea (China) with notes on subgeneric division and phylogenetic relationships. Cahiers de Biologie Marine 43: 179-206.

Murray, K. G., Winnett-Murray, K. \& L. Hertel, 2002. Species diversity, island biogeography, and the design of nature reserves. Tested Studies for Laboratory Teaching 23: 125-143.

Pandolfi, J. M., 1993. A review of the tectonic history of New Guinea and its significance for marine biogeography. In Richmond, R. (ed), Proceedings of the Seventh International Coral Reef Symposium. University of Guam Press, Mangilao: 718-728.

Pesce, G. L., 2007. Harpacticoida. In Copepod web portal. URL: http: www.copepods.interfree.it (last accessed 30.04.2007).

Por, F. D., 1964. A study of the Levantine and Pontic Harpacticoida (Copepoda Crustacea). Zoologische Verhandelingen Leiden 64: 1-128.

Rao, C. G., 1993. Littoral meiofauna of Little Andaman. Records of the Zoological Survey of India: Occasional Papers 155: 1-120. 
Rao, C. G. \& P. N. Ganapati, 1969a. Some new interstitial copepods from Waltair coast. Proceedings of the Indian Academy of Sciences 69: 1-14.

Rao, C. G. \& P. N. Ganapati, 1969b. On some interstitial copepods from the beach sands of Waltair coast. Proceedings of the Indian Academy of Sciences 69: 262-286.

Ridley, M., 2004. Evolution, $3^{\text {rd }}$ edition. Blackwell Science, Oxford.

Santini, F. \& R. Winterbottom, 2002. Historical biogeography of Indo-western Pacific coral reef biota: is the Indonesian region a centre of origin? Journal of Biogeography 29: $189-205$.

Schizas, N. V. \& T. C. Shirley, 1994. Elapholaophonte decaceros n. gen., n. sp. (Copepoda: Harpacticoida, Laophontidae) from the Philippines. Transactions of the American Microscopical Society 113: 127-141.

Schizas, N. V., G. T. Street, B. C. Coull, G. T. Chandler \& J. M. Quattro, 1999. Molecular population structure of the marine benthic copepod Microarthridion littorale along the southeastern and Gulf coasts of the USA. Marine Biology 135: 399-405.

Schizas, N. V., B. C. Coull, G. T. Chandler \& J. M. Quattro, 2002. Sympatry of distinct mitochondrial DNA lineages in a copepod inhabiting estuarine creeks in the southeastern USA. Marine Biology 140: 585-594.

Scott, A., 1909. The Copepoda of the Siboga Expedition. Part I. Free-swimming, littoral and semi-parasitic Copepoda. Siboga Expeditie, Monograph, Leiden 29: 1-323.

Seifried, S., 1997. Three new species of Ectinosoma Boeck, 1865 (Harpacticoida, Ectinosomatidae) from Papua New Guinea and the Fiji Islands. Microfauna Marina 11: $35-58$.

Sewell, R. B. S., 1940. Copepoda Harpacticoida. Reports of the John Murray Expedition: 1933-1934. British Museum of Natural History, édit. 7: 117-382. 
Shen, C. J. \& S. O. Bai, 1956. The marine Copepoda from the spawning ground of Pneumatophorus japonicus (Houttuyn) off Chefoo, China. Acta Zoologica Sinica 8: $177-234$.

Shen, C. J. \& A. Y. Tai, 1963. On five new species, a new subgenus and a new genus of freshwater Copepoda (Harpacticoida) from the delta of the Pearl River, South China. Acta Zoologica Sinica 15: 417-432.

Shen, C. J. \& A. Y. Tai, 1964. Descriptions of new species of fresh water Copepoda from Kwangtung Province, South China. Acta Zootaxonomica Sinica 1: 367-396.

Shen, C. J. \& A. Y. Tai, 1965. Descriptions of six new species of freshwater copepods chiefly from the Pearl River delta, South China. Acta Zootaxonomica Sinica 2: 126-140.

Shen, C. J. \& A. Y. Tai, 1973. Preliminary analysis of the characteristics of the harpacticoid copepod fauna of China and description of some new species. Acta Zoologica Sinica 19: $365-384$.

Soyer, J., C. Thiriot-Quivreux \& J. C. Colomines, 1987. Description de deux espèces jumelles du groupe Tigriopus angulatus (Copepoda Harpacticoida) dans les archipels Crozet et Kerguelen (Terres Australes et Antarctiques Françaises). Zoologica Scripta 16: 143154.

Suárez-Morales, E., M. De Troch \& F. Fiers, 2006. A checklist of the marine Harpacticoida (Copepoda) of the Caribbean Sea. Zootaxa 1285: 1-19.

Tseng, L. C., H. U. Dahms, Q. C. Chen \& J. S. Hwang, 2008. Copepod assemblages of the Northern South China Sea. Crustaceana 81: 1-22.

Urbakh, V. Y., 1975. Statistical analysis in biological and medical studies. Meditsina, Moskow.

Vinogradova, N. G., 1977. Fauna of shelf, continental talus and abyssal. In Monin, A. S. (ed), Biological structure of the Ocean. Nauka, Moskow. Vol. 1: 178-198. 
Voronov, A. G., Drozdov, N. N., Krivoluzkiy, D. A., Mialo, E. G., 2002. Biogeography with fundamental ecology. Vischaya Schkola, MGU, Moskow.

Wells, J. B. J., 1986. Biogeography of benthic harpacticoid copepods of the marine littoral and continental shelf. Syllogeus 58: 126-135.

Wells, J. B. J., H. Kunz \& G. C. Rao, 1975. A review of the mechanisms for movement of the caudal furca in the family Paramesochridae (Copepoda Harpacticoida), with a description of a new species of Kliopsyllus Kunz. Mikrofauna Meeresboden 53: 1-16.

Wells, J. B. J. \& G. C. Rao, 1987. Littoral Harpacticoida (Crustacea: Copepoda) from Andaman and Nicobar Islands. Memoirs of the Zoological Survey of India 16: 1-385.

Willen, E., 2002. Notes on the systematic position of the Stenheliinae (Copepoda, Harpacticoida) within the Thalestridimorpha, and description of two new species from Motupore Island, Papua New Guinea. Cahiers de Biologie Marine 43: 27-42.

Wilson, M. E. J. \& B. R. Rosen, 1998. Implications of paucity of corals in the Paleogene of SE Asia: plate tectonics or Centre of Origin? In Hall, R. \& J. D. Holloway (eds), Biology and geological evolution of SE Asia. Backhuys Publishers, Leiden: 165-195.

Zezina, O. N., 1976. Ecology and dispersal of present brachiopods. Nauka, Moskow.

Zhang, C. \& Z. Li, 1976. Harpacticoida (Copepoda, Crustacea) from Xisha Islands of Guangdong Province, China. Acta Zoologica Sinica 22: 66-70. 


\section{Tables}

Table 1. Characteristics of the Harpacticoida fauna in the different regions of the IndoPacific.

\begin{tabular}{|l|c|c|c|c|}
\hline \multicolumn{1}{|c|}{ Region } & $\begin{array}{c}\text { Number } \\
\text { of } \\
\text { species }\end{array}$ & $\begin{array}{c}\text { Number of } \\
\text { endemics } \\
\text { (\% the total fauna) }\end{array}$ & $\begin{array}{c}\text { Number of } \\
\text { conventional endemics } \\
\text { (\% of the total fauna) }\end{array}$ & $\begin{array}{c}\text { Species/genera } \\
\text { ratio }\end{array}$ \\
\hline $\begin{array}{l}\text { South China Sea } \\
\text { Philippine Islands }\end{array}$ & 77 & $44(57.1 \%)$ & $4(5.2 \%)$ & 1.35 \\
$\begin{array}{l}\text { Sea complex of } \\
\text { Malay Archipelago }\end{array}$ & 41 & $18(60 \%)$ & $6(20 \%)$ & 1.50 \\
New Guinea & 65 & $29(44.6 \%)$ & $5(12.2 \%)$ & 1.37 \\
$\begin{array}{l}\text { Andaman } \\
\text { Nicobar Islands and }\end{array}$ & 184 & $77(42.0 \%)$ & $8(12.3 \%)$ & 1.35 \\
Yellow Sea & 70 & $36(51.4 \%)$ & $78(42.4 \%)$ & 1.94 \\
\hline Total fauna & 402 & $221(55 \%)$ & $23(32.9 \%)$ & 1.52 \\
\hline
\end{tabular}

Java, Banda, Flores and Celebes Seas.

Table 2. Distribution of Harpacticoida species over life form groups in the different regions of the Indo-Pacific.

\begin{tabular}{|c|c|c|c|c|c|c|}
\hline Region & $\begin{array}{l}\text { Epibenthic } \\
\text { species } \\
\text { (\% of the } \\
\text { total fauna) }\end{array}$ & $\begin{array}{c}\text { Genuine } \\
\text { interstitial species } \\
(\% \text { of the total } \\
\text { fauna })\end{array}$ & $\begin{array}{c}\text { Facultative } \\
\text { interstitial species } \\
\text { (\% of the total } \\
\text { fauna })\end{array}$ & $\begin{array}{l}\text { Commensal } \\
\text { species } \\
\text { (\% of the } \\
\text { total fauna) }\end{array}$ & $\begin{array}{l}\text { Macrophyte- } \\
\text { associated } \\
\text { species (\% of } \\
\text { the total fauna) }\end{array}$ & $\begin{array}{l}\text { Planktonic } \\
\text { species } \\
\text { (\% of the } \\
\text { total fauna) }\end{array}$ \\
\hline South China Sea & $47(61 \%)$ & $6(7.8 \%)$ & $13(16.9 \%)$ & $2(2.6 \%)$ & $3(3.9 \%)$ & $6(7.8 \%)$ \\
\hline Philippine Islands & $24(80.0 \%)$ & $1(3.3 \%)$ & $2(6.7 \%)$ & - & - & $3(10 \%)$ \\
\hline $\begin{array}{l}\text { Sea complex of } \\
\text { Malay Archipelago }\end{array}$ & $21(51.2 \%)$ & - & $6(14.6 \%)$ & - & $9(22 \%)$ & $5(12.2 \%)$ \\
\hline New Guinea & $40(61.5 \%)$ & $2(3.1 \%)$ & $6(9.2 \%)$ & $1(1.5 \%)$ & $12(18.5 \%)$ & $4(6.2 \%)$ \\
\hline $\begin{array}{l}\text { Andaman and } \\
\text { Nicobar Islands }\end{array}$ & $110(59.8 \%)$ & $16(8.7 \%)$ & $18(9.8 \%)$ & $1(0.5 \%)$ & $32(17.4 \%)$ & $7(3.8 \%)$ \\
\hline Yellow Sea & $35(50 \%)$ & - & $9(12.9 \%)$ & - & $23(32.9 \%)$ & $3(4.2 \%)$ \\
\hline Total fauna & $252(62.6 \%)$ & $22(5.5 \%)$ & $48(11.9 \%)$ & $3(0.8 \%)$ & $69(17.2)$ & $8(2 \%)$ \\
\hline
\end{tabular}

Java, Banda, Flores and Celebes Seas. 


\section{Figure captions}

Fig. 1. Map of the examined Indo-Pacific regions. The rings, which coincide with single regions, show the total number of species/number of endemic species. Next to the lines (connecting the rings) the Simpson similarity index between species lists of the regions is given. (***_approximate location of the investigated water areas, numbers of stars indicate the level of knowledge of the area. 1-Island Kyushu; 2-Ryukyu Islands; 3-Estuary of Pearl River; 4-Luzon Island; 5-Palawan Island; 6- Mindoro Island; 7 -Cebu Island; 8Mindanao Island; 9-Bali Island; 10-Lombok Island; 11-Obi islands; 12-Aru Islands; 13-Celebes Island; 14—Nicobar Islands; 15-Andaman Islands)

Fig. 2. Cluster dendrogram. Similarity of the Harpacticoida faunas of the studied areas in the Indo-Pacific region ( ${ }^{*}$ Java, Banda, Flores and Celebes Seas). 
Appendix. List of the known harpacticoid copepods of the South China Sea.

In the following list, an asterisk (*) indicates that the species was described from specimens collected in the South China Sea; two asterisks $(* *)$ indicate that the species has not been described yet. The codes indicating life forms are: epibenthic - E, genuine interstitial—GI, facultative interstitial $-\mathrm{FI}$, commensal $-\mathrm{C}$, macrophyte-associated $-\mathrm{M}$, planktonic $-\mathrm{P}$; symbols f\# or m\# indicates that only the female or male of a given species found in NhaTrang Bay is known. Conversely, the lack of such symbols indicates that both sexes were found.

Family AMEIRIDAE Monard

**Ameira sp. (Nha-Trang Bay, Vietnam), FI

Nitokra platypus bakeri Chappuis (Gulf of Thailand, Thailand; Luzon Island, Philippines), FI *Nitokra arctolongus Shen \& Tai (Guangdong province, South China), FI

Nitokra cf. affinis Gurney f\# (Nha-Trang Bay, Vietnam), FI

**Nitokra sp. (Nha-Trang Bay, Vietnam), FI

Family ANCORABOLIDAE Sars

*Paralaophontodes elegans Baldari \& Cottarelli (Mindoro Island, Philippines), E

Family CANTHOCAMPTIDAE Sars

Heteropsyllus sp. f\# (Nha-Trang Bay, Vietnam), E

*Mesochra quadrispinosa Shen \& Tai (Estuary of Pearl River, Guangdong province, South China), FI

Mesochra prowaseki Van Douwe (Guangdong province, South China), FI

Mesochra cf. pygmaea (Claus) f\# (Nha-Trang Bay, Vietnam), FI 
Family CANUELLIDAE Lang

Brianola elegans Hamond (Nha-Trang Bay, Vietnam), E

**Brianola sp. (Nha-Trang Bay, Vietnam), E

\section{Family CLETODIDAE T. Scott}

*Cletocamptus affinis Kiefer (Guangdong province, South China), E

**Cletodes sp. (Nha-Trang Bay, Vietnam), E

**Enhydrosoma sp. (Nha-Trang Bay, Vietnam), E

*Limnocletodes oblongatus Shen \& Tai (Estuary of Pearl River, Guangdong province, South China), E

*Limnocletodes angustodes Shen \& Tai (Estuary of Pearl River, Guangdong province, South China), E

*Schizacron bifurcarostratum (Shen \& Tai) (Estuary of Pearl River, Guangdong province, South China), E

Stylicletodes cf. reductus Wells f\# (Nha-Trang Bay, Vietnam), E

Family DARCYTHOMPSONIIDAE Lang

**Leptocaris sp. (Nha-Trang Bay, Vietnam), GI

\section{Family ECTINOSOMATIDAE Sars}

**Ectinosoma sp. (Nha-Trang Bay, Vietnam), E

**Halectinosoma sp. (Nha-Trang Bay, Vietnam), E

Microsetella rosea (Dana) (Gulf of Thailand, plankton), P 
Microsetella norvegica (Boeck) (Estuary of Pearl River, Guangdong province, South China), $\mathrm{P}$

**Hastigerella sp. (Nha-Trang Bay, Vietnam), GI

Pseudobradya sp. f\# (Nha-Trang Bay, Vietnam), E

Family HUNTEMANNIIDAE Por

*Huntemannia biarticulatus Shen \& Tai (Guangdong province, South China), E

*Nannopus unisegmentatus Shen \& Tai (Estuary of Pearl River, Guangdong province, South

China), E

\section{Family LAOPHONTIDAE T. Scott}

*Apolethon bilobatus Shen \& Tai (Guangdong province, South China), E

*Apolethon trigonus Shen \& Tai (Guangdong province, South China), E

*Carcinocaris serrichelata Cottarelli, Bruno \& Bereira (Mindoro Island, Philippines), C

*Elapholaophonte decaceros Schizas \& Shirley (Luzon Island, Philippines), GI

*Laophonte vitiospinulosa Shen \& Tai (Estuary of Pearl River, Guangdong province, South

China), E

Onychocamptus mohammed (Blanchard \& Richard) (Estuaries, Thailand), E

Paralaophonte sp. f\# (Nha-Trang Bay, Vietnam), E

Quinquelaophonte quinquespinosa (Sewell) (Nha-Trang Bay, Vietnam), E

Xanthilaophonte trispinosa (Sewell) (Mindoro Island, Philippines), C

Family LONGIPEDIIDAE Sars

Longipedia scotti Sars (Nha-Trang Bay, Vietnam), E 
Family MIRACIIDAE Dana

**Amphiascus sp. 1 (Nha-Trang Bay, Vietnam), FI

Amphiascus sp. 2 f\# (Nha-Trang Bay, Vietnam), FI

Amphiascus sp. 3 f\# (Nha-Trang Bay, Vietnam), FI

**Amphiascoides sp. (Nha-Trang Bay, Vietnam), FI

Bulbamphiascus sp. f\# (Nha-Trang Bay, Vietnam), FI

*Cladorostrata brevipoda Shen \& Tai (Estuary of Pearl River, Guangdong province, South China), E

*Cladorostrata longipoda Shen \& Tai (Estuary of Pearl River, Guangdong province, South China), E

Diosaccus sp. f\# (Nha-Trang Bay, Vietnam), E

Macrosetella gracilis (Dana) (South China Sea, plankton), $\mathrm{P}$

Paramphiascella langi (Monard) (Guangdong province, South China), E

Paramphiascella sp. f\# (Nha-Trang Bay, Vietnam), E

**Pararobertsonia sp. (Nha-Trang Bay, Vietnam), E

**Robertgurneya sp. 1 (Nha-Trang Bay, Vietnam), E

Robertgurneya sp. 2 m\# (Nha-Trang Bay, Vietnam), E

Robertsonia cf. knoxi f\# (Thompson \& A. Scott) (Nha-Trang Bay, Vietnam), E

Schizopera clandestina (Klie) (Guangdong province, South China), E

Schizopera longirostris (Daday) (Estuary of Chao Phraya River, Thailand), E

Stenhelia (D.) latioperculata Itô (Nha-Trang Bay, Vietnam), E

*Stenhelia $(D$.$) ornementalia Shen \& Tai (Estuary of Pearl River, Guangdong province, South$ China), E

**Stenhelia (D.) sp. (Nha-Trang Bay, Vietnam), E 
Family PARAMESOCHRIDAE Lang

*Apodopsyllus biarticulatus Cottarelli \& Altamura (Palawan Island, Philippines), GI

**Scottopsyllus sp. (Nha-Trang Bay, Vietnam), GI

**Paramesochra sp. (Nha-Trang Bay, Vietnam), GI

Family PARANANNOPIDAE Por

**Sentiropsis sp. (Nha-Trang Bay, Vietnam), E

Family PARASTENHELIIDAE Lang

Parastenhelia sp. m\# (Nha-Trang Bay, Vietnam), E

Family PELTIDIIDAE Sars

*Clytemnestra hendorffi quinquesetosa Huys \& Conroy-Dalton (Gulf of Thailand, plankton), $\mathrm{P}$

Clytemnestra scutellata Dana (South China Sea, plankton), P

Eupelte acutispinis Zhang \& Li (Estuary of Pearl River, Guangdong province, South China), M

Family TACHIDIIDAE Sars

Euterpina acutifrons (Dana) (Gulf of Thailand, plankton), $\mathrm{P}$

*Microarthridion litospinatus Shen \& Tai (Nha-Trang Bay, Vietnam; Guangdong province, South China), E

*Neotachidius triangularis Shen \& Tai (Estuary of Pearl River, Guangdong province, South China), E 
*Sinotachidius vicinospinalis (Shen \& Tai) (Estuary of Pearl River, Guangdong province, South China), E

Family TETRAGONICIPTIDAE Lang

**Phyllopodopsyllus sp. (Nha-Trang Bay, Vietnam), E

**Diagoniceps sp. (Nha-Trang Bay, Vietnam), E

Family THALESTRIDAE Sars

**Eudactylopus sp. (Nha-Trang Bay, Vietnam), M

*Diarthrodes nhatrangensis (Gómez, Chertoprud \& Morales-Serna) (Nha-Trang Bay, Vietnam), E

*Diarthrodes savinkini (Gómez, Chertoprud \& Morales-Serna) (Nha-Trang Bay, Vietnam), E **Diarthrodes sp. (Nha-Trang Bay, Vietnam), E

Family TISBIDAE Stebbing

Zosime sp. f\# (Nha-Trang Bay, Vietnam), M 
Yellow Sea

Philippine Islands -

South China Sea

* Sea complex of

Malay Archipelago

New Guinea

Andaman and

Nicobar Islands

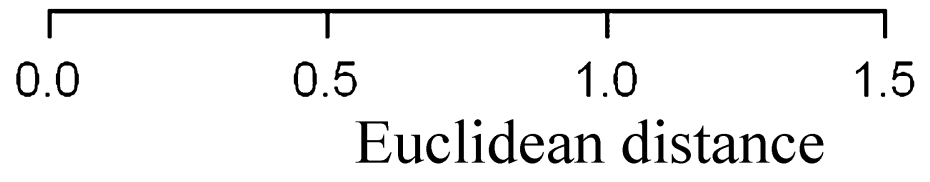

